\title{
The Myth of French Abandonment
}

\section{Jonathan R. Dull}

\begin{abstract}
"Le mythe de l'abandon français" est une critique de la croyance répandue que la France a abandonné le Canada afin de combattre une guerre en Europe. Elle argue du fait qu'avant la guerre le roi Louis XV n'a pas réconcilié la politique française européenne qui favorisait de meilleures relations avec la Grande-Bretagne et sa politique nordaméricaine qui était hostile à la Grande-Bretagne. Dès le commencement de la guerre, cependant, la France a subordonné sa politique européenne à son besoin de sauver le Canada. La révolution diplomatique de 1756 a été conçue pour capturer Hannovre afin de fournir un équivalent pour échanger pour une paix favorable en Amérique du Nord. Les plans français ont échoué quand son nouvel allié, l'Autriche, a été défait par la Prussie à la bataille de Leuthen, condamnant de ce fait au Canada français.
\end{abstract}

Having had a parent die of cancer when I was a teenager, the subject of abandonment is a very personal one for me. One of my purposes in writing The French Navy and the Seven Years' War was to offer reassurance to any Québecois or Québecoise who might feel his or her ancestors had been abandoned by France. In it I argue that this was not the case. It is true that France blundered into a war that it had little chance of winning. Once war started, however, it did everything it could to save New France, its possessions in North America, and briefly came surprisingly close to success. That success was prevented and French Canada doomed by a battle at which no French or British were present, the Battle of Leuthen in what today is Poland. ${ }^{1}$

My brilliant fellow historian Catherine Desbarats has pointed out that the myth of French abandonment has at least alleviated any feelings that the people of New France were responsible for their own defeat. ${ }^{2}$ I believe that fault finding is pointless. Both

1 Jonathan R. Dull, The French Navy and the Seven Years' War (Lincoln, Nebraska and London: University of Nebraska Press, 2005). Unless otherwise noted the present essay is based on it.

2 Catherine Desbarats and Allan Grier, "The Seven Years' War in Canadian History and Memory," in Warren R. Hoffstra, ed., Cultures in Conflict: The Seven Years' War in North

The Northern Mariner/le marin du nord, XIX No. 1, (January 2009), 1-6 
Frenchmen and French Canadians fought gallantly and skillfully against almost impossible odds. Even had the battle on the Plains of Abraham ended differently French Canada was doomed by events in Europe. What I will discuss here is the relationship between the loss of Canada and what happened in Europe. In the process I hope to make two points. First is the enormous importance of geography. Napoleon once wrote that the foreign policy of all states is based on their geography. ${ }^{3}$ The central strategic reality of French Canada was based on its geography. Canada lay so far north that its growing season was too short to feed armies large enough to defend it. French diplomacy had to take this into account. The second point is that during the Seven Years' War New France was not peripheral to French diplomacy, but central. Indeed it can be argued that the French did not prize New France too little but too much, because they launched a huge, bloody, and expensive war in Germany to try to save it.

Let me first provide some background. It is a common belief that Britain and France were natural enemies during the eighteenth century, doomed to hostility by commercial and colonial rivalry. This is not so. The opposite point can be made. Because their security in Europe was more important than their competition abroad, Britain and France were natural allies. In support of this let us look at the brief period in which they actually were allies. After the death of King Louis XIV in 1715 France and Britain became allies, because their rulers, King George I and the French regent Philippe, duc d'Orléans, shared an interest in peace, in dynastic stability, and in preserving the existing map of Europe. Their alliance soon brought peace and security not only to France and Britain, but to all of Europe. For the dozen years between 1721 and 1733 all of Europe was at peace except for a virtually bloodless conflict between Britain and Spain. Without either France or Britain to bankroll them the other powers of Europe could not afford a war. There was even a rudimentary system for adjudicating diplomatic disputes based on diplomatic congresses. This was the longest period of peace over the entire continent that Europe had ever known. ${ }^{4}$ Later French statesmen regarded the period of the British alliance as a golden age and on several occasions tried to establish better relations. Even in North America it was a period of relative peace to which the Iroquois contributed by forming a buffer zone between New France and the northern British colonies.

By the end of the period George and Philippe had died. George's son, King George II, and Philippe's successor, French Chief Minister Cardinal Fleury accepted the alliance but without enthusiasm. The two countries drifted apart. In 1733 France went to war with Russia and with Britain's new ally Austria. British prime minister Robert

America (Lanham, Maryland and elsewhere: Rowman \& Littlefield, 2007), 145-178.

3 In a November 4, 1804 letter to King Frederick William III of Prussia quoted in Albert Sorel, L'Europe et la Révolution française (8 vols., Paris: Plon-Nourrit et Cie., 1887-1904), 6: 400401. The translation is mine.

4 Jonathan R. Dull, "Great Power Confrontation or Clash of Cultures?: France's War against Britain and Its Antecedents," in Hofstra, Clash of Cultures, 65. I will discuss this period in greater detail in my forthcoming book The Age of the Ship of the Line: The British and French Navies, 1650-1815 (Lincoln, Nebraska and London: University of Nebraska Press, 2009). 
Walpole kept Britain out of the war, but the Franco-British alliance had lost its meaning. In 1739 Britain in turn went to war with France's new ally Spain. France gave assistance to Spain but avoided becoming directly involved in the war, more by luck than design. Soon thereafter, however, the ruler of Austria died. King Louis XV, who had reached adulthood, disregarded Fleury's warnings, and joined with Prussia in attacking Austria. This brought Britain into the war in support of Austria. A British and a French army fought in Germany as auxiliaries of Austria and of France's German allies. Finally in 1744 the two counties declared war on each other. This war, the War of the Austrian Succession, had devastating consequences for their future relations. It would be seventy years before a stable peace was restored and during those seventy years the two countries fought five wars.

The War of the Austrian Succession, also known as King George's War, also disrupted the balance of power in North America. Raids by Canadians and Native Americans swept the frontiers of the British colonies. In return Massachusetts troops and a British squadron captured the great fortress of Louisbourg. The 1748 Treaty of Aix-laChapelle, which ended the war, restored Louisboug to New France. What could not be restored was the French alliance system with the native nations south of the Great Lakes. Because the war disrupted the supply of French trade goods on which these nations depended they turned to the British-Americans merchants who poured into the area, particularly the area around the headwaters of the Ohio River.

In spite of the changed circumstances in North America, the Treaty of Aix la Chapelle did not guarantee another war between France and Britain. Compared to the peace signed by Napoleon in 1802, for example, its terms were remarkably moderate. France gave up all of the Austrian Netherlands, today's Belgium, as well as Madras in India in order to make peace and recover Louisbourg. The French public was so disgusted with these terms that it coined the expression, "Stupid as the peace." In fact the treaty was a model of wisdom and common sense. The marquis de Puyzieulx, the able French foreign minister, was willing to forego territorial gains in order to establish France's reputation for moderation. He could afford to do so because Prussia had taken the rich province of Silesia from Austria and thereby established a balance of power in Germany. With Austria no longer a menace Puyzieulx began constructing a series of alliances against Russia, which he regarded as the greatest long-term threat to France's allies in eastern Europe. He even sought better relations with Britain, earning the respect of the Earl of Albemarle, the British ambassador at the French court. He could not overcome the mistrust of the British public, however, which was outraged by French support of the Stuart uprising of 1745 in Scotland. For the moment, however, France and Britain no longer threatened each other in Europe.

Even in North America hostilities were not inevitable. Britain and France were able to contain the greatest danger, along the disputed border of Acadia, now the border between Nova Scotia and New Brunswick. Instead the confrontation came in an area of small economic importance, the region around what is today western Pennsylvania. Except for the fisheries off its eastern border New France was an economic liability to France, because the furs it produced had a limited market. The area in question produced 
few furs, but it was not far from the main route between Canada and Louisiana via the Maumee, Wabash, Ohio, and Mississippi Rivers. A series of inexperienced governors general of New France were frightened that the British trade penetration of the area eventually would threaten this route. They convinced the equally inexperienced French naval and colonial minister, Antoine-Louis Rouillé. Instead of winning back the loyalty of the native nations of the area by generosity and trust, the French elected a military solution. This culminated in Governor General Duquesne's fort building program south of Lake Erie which alienated nations like the Shawnee and Delaware, frightened the British, and finally led to a military confrontation with Virginia troops led by George Washington.

Rouillé was as inept a naval minister as he was a colonial minister. He built enough warships to disturb the British but not enough to challenge them and at the end of 1752 ceased filling the navy's dockyards with the supplies it would need to fight a war. ${ }^{5}$ France thus blundered into a war it was unprepared to fight. Ironically, when the crisis came Rouillé had switched positions in the council of state and was now the foreign minister who conducted the unsuccessful negotiations to avert war. The deepest blame, however, belongs to those in Britain, like the Duke of Cumberland, who undercut the negotiations and to King Louis XV, who failed to resolve the conflicting policies of the French foreign ministry and the French naval and colonial ministry. ${ }^{6}$

Someone once commented about the Bourbon kings of France that they remembered everything and learned nothing. This may have been true of King Louis XVI, but it was not true of his predecessors. King Louis XIV learned to hate war, and King Louis XV learned to accept responsibility. Once open hostilities with Britain began he acted with considerable intelligence and decisiveness. To lose New France would be an intolerable humiliation that would undermine the confidence of France's allies and thus threaten French security. New France, however, was indefensible in the long run because it could barely feed itself let alone an army large enough to defend it. Fortunately the French Navy was now in the good hands of an able minister, Jean-Baptiste Machault. With luck it could buy time for New France but eventually the far larger British Navy would be able to cut its connections with France. The only question was whether New France then would succumb to hunger or to the huge armies Britain could send to its North American colonies with their ample food supplies. In the decisive year of 1759 some 40,000 British and British-American troops were able to overcome 15,000 French and French Canadian troops, two-thirds of them militia.

Only in Europe could France save Canada, much as it had obtained restoration of Louisboug in 1748. Louis XV had three choices. He could attack the Austrian Netherlands again, knowing that Britain could not risk France's obtaining a possession so close to the shores of England. The previous conquests had been extremely costly, however, and had depended on the genius of the French commanding general, Marshal

5 James Pritchard, "Fir Trees, Financiers, and the French Navy during the 1750's," Canadian Journal of History 23 (1988), 347.

6 The best account of the negotiations is T. R. Clayton, "The Duke of Newcastle, the Earl of Halifax, and the American Origins of the Seven Years' War," Historical Journal 24 (1981), 571-603. 
Saxe, who was now dead. Moreover, the Austrians were now signalling their desire for an alliance with France. Louis thus rejected that option. A second option was capturing the valuable British island of Minorca in the Mediterranean and exchanging it for a reasonable settlement in North America. The French were able to do so, but the British did not decide to make peace. Instead they used Admiral John Byng, the commander of a British squadron which failed to relieve Minorca, as a scapegoat. In Voltaire's immortal expression, they shot him in order to encourage their other admirals. The final option was to capture for future exchange the electorate of Hanover in northern Germany, ruled by King George II of England. Hanover was of major economic and strategic importance and its elector, George, treasured it far more than he did anything in North America. To attack Hanover, however, would require Austrian cooperation that could only be obtained in exchange for French cooperation in Austria's attacking Prussia to regain Silesia. This would require the reversal of two centuries of French foreign policy. Louis XV was willing to do so to save New France. On 1 May 1756 his representatives signed a treaty of defensive alliance with Austria, which would require either party to come to the assistance of the other if it were attacked. This was the first stage of the so-called Diplomatic Revolution, which ended with France allied to its former enemy Austria and Britain allied with its former enemy Prussia.

Few events in diplomatic history have been as widely misinterpreted as the Diplomatic Revolution. Abbé Bernis, who negotiated it and became French foreign minister, claimed that its aim was to keep France out of war in Europe. Historians generally have believed him. One exception is Léon Cahen, who in a review of Bernis' memoirs written a hundred years ago, pointed out that Bernis was a consummate liar. ${ }^{7}$ In fact as soon as the defensive alliance was signed negotiations began for an offensive alliance, so that France could obtain an equivalent for Austria's regaining Silesia. (Louis finally settled for the Austrian Netherlands being promised to his son-in-law Prince Philip of Parma in exchange for his possessions in Italy.) France's goal from the very beginning was that of capturing Hanover. The ensuing French war in Germany was not a betrayal of Canada for European aims; it was the launching of a war against the Hanoverians, who wished only peace, in order to save Canada.

Initially the Diplomatic Revolution was a great success for France. King Frederick II of Prussia launched an unsuccessful preemptive strike against Austria, greatly facilitating the Franco-Austrian negotiations that ended in an offensive alliance. In 1757 Machault's brilliant strategy brought much of the French Navy to Louisbourg, where it foiled a British attack. The French army in Germany defeated a Hanoverian and other German army commanded by the Duke of Cumberland and captured Hanover. Meanwhile an Austrian army captured Breslau, the capital of Silesia. By all odds the war should have ended in late 1757 with the British forced to make a settlement in North America in order to regain Hanover and Minorca. Almost miraculously, Frederick the Great, prepared to commit suicide if he did not recapture Breslau, defeated the Austrian army at nearby Leuthen. Within weeks Breslau was recaptured and the Hanoverian Army

7 Léon Cahen, "Les Mémoires du Cardinal Bernis et les débuts de la Guerre de Sept ans," Revue d'histoire moderne et contemporaine 12 (1909), 73-99. 
reentered the war, now under the command of a Prussian general, Ferdinand of Brunswick. ${ }^{8}$ Even the great French accomplishment at Louisbourg ended disastrously, as an epidemic swept the French fleet, killing half its sailors. French Canada now was doomed.

The French Navy persevered in trying to save Canada. In 1758 it devoted an even larger share of its resources to Louisbourg then it had in 1757. In the previous year 18 of the navy's 42 ships of the line had been sent to Canada; this year it tried to send 16 of the 30 it was able to man (plus a ship of the line on loan from the French East India Company). The British had about 100 of the line each year. It sent 16 to Louisbourg in 1757 and 23 in 1758. The French task was hopeless, particularly since not all the ships it sent arrived safely. A huge effort was mounted simultaneously to provision the French army in Canada. The French intendant at Bordeaux even complained that his region was in danger of food shortages because so much was being sent to Canada. Private merchants joined in, like the great Jewish merchant of Bordeaux Abraham Gradis, who sent 14 ships to Canada, only one of which returned safely. ${ }^{9}$ It was largely the generosity and patriotism of people like him that saved Quebec from starvation.

By the following year France had a new foreign minister, the valiant duc de Choiseul and a new strategy, that of saving Canada by invading England. As a result no ships of the line were sent to Quebec although major efforts again were made to provide supplies for Montcalm's army. For all his courage and dedication Choiseul was a landlubber like Napoleon and his frantic efforts failed. The focus of the war now changed. The ruthless William Pitt sought to destroy France as a naval power by denying it access to the Newfoundland and St. Lawrence fisheries, on which the training of a major part of its fleet depended. All hope of regaining Canada had to abandoned in order to save the future of the French Navy. Once again the French turned to the war in Germany and finally they succeeded. Although they could not capture Hanover again they did take nearby Cassel, the capital of Hanover's chief ally. The British taxpayer finally wearied of the seemingly endless and prohibitively expensive war in Germany. To end the war Prime Minister Bute conceded the French a share in the fishery and returned their Caribbean islands of Guadeloupe and Martinique. (The pamphlet war in Britain about whether to retain Canada or Guadeloupe was purely academic, since the decision ultimately was in France's hands. $)^{10}$ Pitt, out of office, bitterly blamed Bute for giving France the chance to rebuild its navy. Fifteen years later he would be proven right. Louis XV lost Canada but he saved the French Navy and became posthumously a major architect of American independence. This, however, is a story for another day.

8 For the Battle of Leuthen and its consequences see Christopher Duffy, Prussia's Glory: Rossbach and Leuthen 1757 (Chicago: The Emperor's Press, 2003) and Franz A. J. Szabo, The Seven Years War in Europe, 1756-1763 (Harlow, England and elsewhere: Pearson / Longman, 2008), 89-112. For the campaigns of Ferdinand of Brunswick see Sir Reginald Savory, His Britannic Majesty's Army in Germany during the Seven Years' War (Oxford: Clarendon Press, 1966).

9 For Gradis see Jean de Maupassant, Un Grand Armateur de Bordeaux, Abraham Gradis (1699?-1780) (Bordeaux: Ferret et fils, 1917).

10 The pamphlet literature is described in William L. Grant, "Canada versus Guadeloupe, an Episode of the Seven Years' War," American Historical Review 17 (1911-12), 735-743. 